\title{
Infections Independent of Contamination: From Organic Matter, Evolution or Stem Cells
}

\author{
Alen J Salerian* \\ Modern Psychiatry, 40 Nestoros street,Vavrona, 19016 Greece
}

*Corresponding author: Alen J Salerian, Modern Psychiatry, 40 Nestoros street,Vavrona, 19016 Greece, Tel: 306987428063; E-mail: alensalerian@gmail.com

\begin{abstract}
This study presents evidence to propose that some human infections may derive independent of contamination by invading pathogens.

Diverse data suggest multiple pathways independent of contamination may generate human infections. For instance, the first microorganisms that emerged from lifeless organic matter 3.6 billion years ago indicated transformation of lifeless organic matter to micro organisms. Viral infections do correspondent to a lifeless protein particle in a cell of a complex multi- cellular organism reproducing and spreading infections to other complex multi- cellular organisms.
\end{abstract}

Some microbes -such as pseudomonas aeruginosa with a larger genome and greater functional complexity than common bacteria -may evolve from human flora as observed in mammalian decomposition in sterile soil. For, decomposer species are not foreign Invaders from the environment and they represent evolution of common microorganisms during mammalian decomposition. Human cells may produce microorganisms consistent with a proven genetic link between humans cells and the Christensenellaceae (a family in the phylum Firmicutes). Human stem cells which are capable to differentiate to epithelial cells and cancer and have the essentials to produce microbes are the most likely candidates to produce microorganisms.

What may be almost certain and not experimentally validated is the possibility that infections have multiple pathways of origin independent of contamination. Most nosocomial and opportunistic infections may be endogenous. Our knowledge may demolish the dogma of contamination by foreign microbes as the exclusive source of infections and pave novel avenues to prevent and treat diverse infections.

\section{HIGHLIGHTS}

- Infections may not only result from contamination by foreign pathogens but also from organic matter transforming to microbes or a protein particle reproducing in a cell of an animal (viral and prion associated disorders )or human stem cells generating microorganisms and or normal human flora evolving to more complex pathogens.
- Most nosocomial and opportunistic infections may be endogenous.

- Some infections are heritable.

- Without any invading pathogens from the environment, the human body and its 37 trillion cells and 37 trillion resident microbes represent a fertile harbor for new microbes. 


\section{Perspective}

Since the introduction of the germ theory [1] in mid- $19^{\text {th }}$ century, contamination by invading bacteria from the environment has been viewed as the primary cause of infections.

This study offers evidence consistent with the observation that some human infections may result independent of contamination by foreign pathogens and derive from organic matter transforming to microbes or a protein particle reproducing in a human cell (viral and prion associated disorders) or human stem cells generating microorganisms and or normal human flora evolving to more complex pathogens.

Hereby I present the evidence consistent with the multiple pathways of origin of infections under the following headlines:
A. Contamination
B. Organic Matter
C. Evolution of Simple Microbes to Complex Microbes
D. Protein Particles
E. Stem Cells

\section{A. Contamination}

Since the introduction of the germ theory [1] in mid- $19^{\text {th }}$ century, contamination by invading bacteria from the environment has been viewed as the primary cause of infections.

\section{B. Organic Matter}

How was the first microorganism born?

Science says life on earth began from lifeless organic matter 3.6 billion years ago [2]. If true, it means some infections may result from organic matter [3]. It is also reasonable to believe that, transformation of organic matter to living organisms was not a one time occurrence and continues to be a major and active pathway of pathogens.

\section{Evolution Simple Microbes to Complex Microbes}

Charles Darwin suggested that all species are related and some species including microorganisms may evolve from less complex microorganisms [4]. Thus, it seems quite likely that some microbes -such as pseudomonas aeruginosa which has a larger genome and greater cellular and functional complexity than common bacteria [5,6] may evolve from human flora as observed in mammalian decomposition [7-9]. This observation is supported by recent studies suggesting that decomposer species including Pseudomonas are not foreign Invaders from the environment and they represent evolution of common microorganisms during mammalian decomposition [7-9]. For instance, it has been shown that, mammalian decomposition takes place in sterile soil or in tightly insulated pig carcasses wrapped in plastic, submerged in water, suggesting that some of decomposer species are endogenous and evolve from resident flora [7-9].

\section{Protein Particles}

A protein particle known as a virion, consists of nucleic acid surrounded by a protective coat of protein called a capsid. reproducing in a human cell may cause viral infections [10]. In a similar way a prion may produce in an animal cell and cause prion associated disorders [11].

\section{E. Stem Cells}

The most compelling evidence to suggest that human cells may produce microorganisms is the observation of a genetic link between humans cells and the Christensenellaceae (a family in the phylum Firmicutes) [12]. There is also evidence that Malassezia furfur yeasts [13] are heritable. It seems reasonable to consider that human stem cells which are capable to differentiate to epithelial cells and cancer and have the essentials to produce microbes are the most likely candidates to produce microorganisms [14].

Furthermore, In the last decade diverse molecular observations have revealed the existence of endogenous microorganisms in several body parts which had previously been thought to be sterile. For instance it has been shown that breast milk [15] breast tissue [16], amniotic fluid [17,18] placenta $[19,20]$ umbilical cord blood [21], meconium [22] harbor bacterial communities. Of significance, there has been no evidence to suggest that fetal microorganisms are contaminants from the environment. Also, the composition of the bacterial communities is unique for each habitat suggesting that they may have different origins [23,24].

\section{DISCUSSION}

What seems certain is the germ theory (contamination by microorganisms from the environment causing infections) is experimentally validated and true. However, what is almost certain yet not experimentally validated is the possibility that infections have multiple pathways of origin independent of contamination.

What do these findings infer?

Our knowledge may demolish the dogma of contamination by foreign microbes as the exclusive source of infections and pave novel avenues to prevent and treat diverse infections. 


\section{REFERENCES}

1. Pasteur L (1880) And the extension of the germ theory to the aetiology of certain common diseases. Comptes rendus del'Academie des Sciences.xc.Ernst,(Ttrans) 1033-1044.

2. Cavalier-Smith T (2006) Cell evolution and Earth history: Stasis and revolution. Philosophical transactions Royal Society in London Biological Sciences 361: 969-1006.

3. Salerian AJ (2017) Human body may produce bacteria. Medical Hypotheses 103: 131-132.

4. Salerian AJ (2021) Some Infections May Be Endogenous. Biomed Transl Sci 1: 1-3.

5. Darwin C (1859) On the Origin of Species by Means of Natural Selection, or the Preservation of Favoured Races in the Struggle for Life.

6. Stover CK, Pham XQ, Olson MV (2000) Complete genome sequence of Pseudomonas aeruginosa PAO1, an opportunistic pathogen. Nature 406: 959-964.

7. Salerian AJ (2020) Burn wound infections and Pseudomonas aeruginosa. Burns 46: 257-258.

8. Lauber CL, Metcalf JL, Keepers K, Ackermann G, Carter DO, et al. (2014) Vertebrate Decomposition Is Accelerated by Soil Microbes. Applied and Environmental Microbiology 80: 49204929.

9. Salerian AJ (2020) What is the origin of decomposer species? Journal of Applied \& Environmental Microbiology 8: 6-7.

10. Breitbatr M, Rohwer F (2005) Here a virus, there a virus, everywhere the same virus? Trends in Microbiology 13: 278-284.

11. Brown P, Will RG, Bradley R, Asher DM, Detwiler L (2021) Bovine spongiform encephalopathy and variant CreutzfeldtJacob disease: Background evolution and current concerns. Emerging Infectious Diseases 7: 6-16.

12. Waters JL, Ley RE (2019) The human gut bacteria Christensenellaceae are widespread, heritable, and associated with health. BMC Biol 17: 83.

13. He SM, Du WD, Yang S, Zhou SM, Li W, et al. (2007) The genetic epidemiology of tinea versicolor in China. Mycoses 51: 55-62.
14. Van der Flier LG, Clevers H (2009) Stemcells, Self Renewal, and Differentiation in the intestinal Epithelium. Annual Review of Physiology 71: 241-260.

15. Martin R, Langa S, Reviriego C, Jiminez E, Marin ML, et al. (2003) Human milk is a source of lactic acid bacteria for the infant gut. The Journal of Pediatrics 143: 754-758.

16. Urbaniaak C, Cummins J, Brackstone M, Macklaim JM, Gloor GB, et al. (2014) Microbiota in human breast tissue. Appl Environ Microbiology 80: 3007-3014.

17. Di Giulio DB (2012) Diversity of microbes in amniotic fluid. Seminars in Fetal and Neonatal Medicine 17: 2-11.

18. Collado M, Rautava S, Aakko J, Isolauri E, Salminen S (2016) Human gut colonisation may be initiated in utero by distinct microbial communities in the placenta and amniotic fluid. Sci Rep 6: 23129.

19. Jiménez E, Fernández L, Marín ML, Martin R, Odrizola JM, et al. (2005) Isolation of Commensal Bacteria from Umbilical Cord Blood of Healthy Neonates Born by Cesarean Section. Curr Microbiol 51: 270-274.

20. Stout MJ, Conlon B, Landeau M, Lee I, Bower C, et al. (2008) Identification of intracellular bacteria in the basal plate of the human placenta in term and preterm gestations. American Journal of Obstetrics and Gynecology 208: e1-7.

21. Aagaard K, Ma J, Antony KM, Ganu R, Petrosino J, et al. (2014) The Placenta Harbors a Unique Microbiome. Science Translational Medicine 6: 237ra65.

22. Jimenez E, Marin ML, Matin R, Odriozola JM, Olivares M, et al. (2008) Is fetal meconium sterile? Research in Microbiology 159: 187-189.

23. Ardissone AN, DeLa Cruz D, Davis- Richardson AG, Rechigi KT, et al. (2014) Meconium microbiome analysis identifies bacteria correlated with premature birth. PLOS ONE 9: e90784.

24. Jimenez E, Fernandez L, Marin ML, Martin R, Odrizola RM, et al. (2005) Isolation of Commensal Bacteria from Umbilical Cord Blood of Healthy Neonates Born by Cesarean Section. Current Microbiology 51: 270-274 